\title{
DAMPAK PERLAKUAN MODEL PEMBELAJARAN RADEC BAGI CALON GURU TERHADAP KEMAMPUAN MERENCANAKAN PEMBELAJARAN DI SEKOLAH DASAR
}

\author{
Hany Handayani ${ }^{1}$, Wahyu Sopandi², Ernawulan Syaodih ${ }^{3}$, Dadan Setiawan ${ }^{4}$, \\ Indra Suhendra ${ }^{5}$ \\ ${ }^{1}$ Program Studi Pendidikan Guru Sekolah Dasar, Sekolah Tinggi Keguruan IImu \\ Pendidikan Purwakarta, Jl. Veteran No 54 Purwakarta 54324, Indonesia. \\ 2,3,4,5 Universitas Pendidikan Indonesia, Bandung, Indonesia. \\ 1'hanyhandayani011117@gmail.com
}

\begin{abstract}
Developing the skills of prospective teachers in planning learning is one of the main goals in education. The purpose of this study is to describe the impact of applying the RADEC learning model (Read, Answer, Disscuss, Explain, and Create) on the ability of prospective teachers to plan learning in elementary schools. The research method used in this study is a quasi-experimental method with one shot case study design. The population in the study amounted to 40 . The number of samples of this study amounted to 9 prospective teachers. Data obtained through observation, and study documentation of the results of lesson plans that have been made by prospective teachers. The results are analyzed and assessed based on the developed learning ability assessment planning instrument. Based on the results of the study, the results obtained that the average score of the ability of prospective teachers in planning learning is 95.39. This shows that the RADEC learning model has a good impact on the ability of prospective teachers to plan learning.
\end{abstract}

Keywords: Ability to plan learning, RADEC model.

\begin{abstract}
ABSTRAK
Mengembangkan keterampilan calon guru dalam merencanakan pembelajaran adalah salah satu tujuan utama dalam pendidikan. Tujuan dari penelitian ini adalah untuk mendeskripsikan dampak penerapan model pembelajaran RADEC (Read, Answer, Disscuss, Explain, and Create) terhadap kemampuan calon guru dalam merencanakan pembelajaran di sekolah dasar. Metode penelitian yang digunakan dalam penelitian ini adalah metode kuasi eksperimen dengan desain one shot case study. Populasi dalam penelitian berjumlah 40. Adapun jumlah sampel penelitian ini berjumlah 9 orang calon guru. Data diperoleh melalui observasi, dan studi dokumentasi hasil rencana pelaksanaan pembelajaran yang telah dibuat oleh calon guru. Hasil tersebut dianalisis dan dinilai berdasarkan instrument penilaian kemampuan merencanakan pembelajaran yang sudah dikembangkan. Berdasarkan hasil penelitian, diperoleh hasil bahwa skor rata-rata kemampuan calon guru dalam merencanakan pembelajaran sebesar 95,39. Hal tersebut menunjukkan bahwa model pembelajaran RADEC memiliki dampak yang baik terhadap kemampuan calon guru dalam merencanakan pembelajaran.
\end{abstract}

Kata kunci: Kemampuan Merencanakan Pembelajaran, model RADEC. 


\section{A. Pendahuluan}

Pengajaran dan pendidikan merupakan suatu proses yang dilakukan secara sadar akan tujuan, tujuan dapat diartikan sebagai suatu usaha untuk rumusan capaian pembelajaran yang hendak dicapai siswa ketika selesai pembelajaran (Sardiman, 2004). Tercapai atau tidaknya tujuan yang telah dirancang oleh guru dapat dilihat dari prestasi hasil belajar yang diraih oleh siswa, dengan prestasi yang tinggi diindikasi bahwa siswa melikiki pengetahuan yang baik (Hamdu \& Agustina, 2011). Model pembelajaran RADEC (Read, Answer, Disscuss, Explain, and Create) merupakan model pembelajaran yang dapat mendorong siswa untuk mengembangkan keterampilan abad ke-21 dan menguasai konsep pembelajaran yang dipelajari (Sopandi, 2017).

Model pembelajaran RADEC dikembangkan

berdasarkan beberapa hal berikut. Pertama, model ini didasarkan pada tujuan pendidikan nasional yakni untuk mengembangkan segenap potensi yang dimiliki siswa menjadi manusia yang beriman kepada Tuhan, luhur, sehat, berpengetahuan, cakap, kreatif, mandiri, dan menjadi warga negara yang demokratis serta bertanggung jawab (Pemerintah Republik Indonesia, 2003). Kedua, model ini dikembangkan atas dasar teori kontruktivisme. Menurut Vygotski (1962) mengemukakan bahwa kemampuan kognitif pada anak-anak dapat berkembang melalui interaksi dengan lingkungan sosial. Pada teori ini, dikenal dengan istilah Zona Pengembangan Proksimal (ZPD). Jadi dalam proses pembelajaran, ada masa dimana siswa perlu belajar secara mandiri tentang suatu konsep materi pelajaran tanpa bantuan oleh orang lain. Hal ini bertujuan untuk melihat kemampuan siswa tanpa bantuan pihak lain dan kemampuan yang hanya dapat dicapai dengan bantuan pihak lain (tingkat perkembangan potensial). Atas dasar teori tersebut, maka dalam proses pembelajaran guru harus melakukan pembelajaran diantara hal tersebut.

Model pembelajaran RADEC memiliki karakteristik dalam pembelajaran diantaranya adalah: (1) pembelajaran RADEC senantiasa mendoorng siswa untuk terlibat secara aktif dalam proses pembelajaran; (2) pembelajaran RADEC mendorong siswa untuk belajar secara mandiri; 
pembelajaran RADEC senantiasa menghubungkan apa yang diketahui siswa dengan materi yang dipelajari; (4) pembelajaran

RADEC menghubungkan materi yang dipelajari dengan kehidupan nyata atau isu-isu kontemporer; pembelajaran RADEC senantiasa memberikan peluang bagi siswa untuk aktif mengajukan pertanyaan, berdiskusi, mengajukan rencana penyelidikan, dan menyimpulkan materi yang dipelajari; pembelajaran RADEC memberikan peluang kepada siswa untuk mempelajari materi secara mendalam melalui tugas prapembelajaran.

Prinsip dasar dari model pembelajaran RADEC ini adalah bahwa semua siswa memiliki potensi dan kapasitas untuk belajar secara mandiri dan belajar lebih tinggi untuk menguasai pengetahuan dan keterampilan (Sopandi, 2017). Langkah-langkah model RADEC mendorong siswa untuk melakukan berbagai aktivitas dalam pembelajaran seperti membaca, menjawab, berdiskusi, menjelaskan, mengeksplorasi, melakukan penyelidikan, dan memecahkan masalah, serta membuat karya. Selain itu, dalam pembelajaran menggunakan model RADEC menuntut siswa untuk membuat rencana penyelidikan atau merencanakan proyek secara mandiri. Proses pembelajaran yang memungkinkan siswa untuk melakukan berbagai aktifitas selama pembelajaran dan melibatkan siswa dalam menentukan topik yang akan dipelajari dan diselidiki dapat mengembangkan keterampilan berpikir dan memberikan rasa kepemilikan, tanggungjawab, dan keterlibatan dalam pendidikan (Allison \& Allison, 2018; Zandvakili, Washington, Gordon, \& Wells, 2018). Sejalan dengan hal tersebut, model pembelajaran RADEC telah terbukti mampu meningkatkan penguasaan konsep dan mengembangkan keterampilan menjelaskan siswa (Sopandi \& Handayani, 2019; Lukmanudin, 2018; Sopandi, 2017).

Model pembelajaran RADEC memiliki beberapa keunggulan diantaranya yaitu dapat mendorong siswa untuk beroleh keterampilan abad ke-21. Pada abad ke-21 ini ada beberapa keterampilan yang harus dimiliki oleh manusia yaitu pemahaman konseptual, berpikir kritis, kolaborasi dan komunikasi, dan berpikir kreatif (Morocco, Aguilar, \& 
Bershad, 2010; Brinkley et. al., 2012). Keunggulan model RADEC lainnya adalah tahapan dari model ini mudah untuk dipahami dan diingat oleh guru. Hal ini terbukti dari penelitian yang dilakukan oleh Handayani \& Sopandi (2019) yang hasilnya adalah sebanyak $97,2 \%$ guru yang mengikuti pelatihan tertarik untuk mengimplementasikan model pembelajaran RADEC di sekolah karena mudah untuk dipahami dan hasil implementasi di sekolahnya pun dapat membantu siswa untuk membangun karakter, meningkatkan pemahaman konseptual siswa dan mendorong siswa untuk mengembangkan kompetensi abad ke-21. Lebih lanjut, model pembelajaran RADEC juga memiliki keunggulan yang lain yaitu langkahlangkah pembelajarannya mudah untuk dipahami oleh guru, karena langkah-langkahnya terlihat dari singkatan dari nama model itu tersendiri yaitu Read, Answer, Disscuss, Explain, and Create. Kemudahan dalam mengingat dan mengimplementasikan model pembelajaran RADEC ini terbukti dari penelitian-penelitian sebelumnya yang menyatakan bahwa langkahlangkah model RADEC mudah untuk dihafal dan dipahami serta dapat membantu siswa untuk membangun budaya membaca, meningkatkan literasi siswa, meningkatkan pemahaman konseptual siswa dan mendorong siswa untuk mengembangkan kompetensi abad ke-21 (Sopandi, Pratama, \& Handayani, 2019; Handayani \& Sopandi, 2019).

Sekait dengan penjelasan di atas, secara singkat dapat disimpulkan bahwa model pembelajaran RADEC memiliki keunggulan dalam meningkatkan kemampuan belajar. Pada penelitian ini, peneliti mendeskripsikan dampak model pembelajaran RADEC terhadap kemampuan calon guru dalam merencanakan pembelajaran di sekolah dasar. Kemampuan merencanakan pembelajaran merupakan kemampuan yang esensial dan paling kritis yang harus dimiliki oleh setiap calon guru (Herman, 2007). Hal ini dikarenakan membuat perencanaan pembelajaran merupakan salah satu tugas utama menjadi seorang guru professional (Kependidikan, JENDERAL, Kependidikan, \& NASIONAL, 2008). Dalam (Sudjana, 1983) mengemukakan bahwa kompetensi 
guru yang banyak hubungannya dengan usaha untuk meningkatkan keteramplinan proses dan hasil belajar dapat dirumuskan dalam empat kemampuan yakki merencanakan program belajar mengajar, melaksanakan atau mengelola proses belajar mengajar, menilai kemajuan yang telah dicapai pada proses pembelajaran dan menguasai bahan pelajaran. Guru sudah bukan lagi sebagai pemberi ceramah dnan penyaji informasi melainkan mengutamakan kemampuan merencanaknan, dan pengelolaan kelas (Saragih, 2008). Kegiatan merencanakan pembelajaran merupakan kegiatan yang penting karena dengan perencanaan yang baik akan menghasilkan proses pembelajaran yang baik pula (Nurgiyantoro, 2010).

\section{Berdasarkan}

penjelasan

tersebut di atas, begitu pentingnya kemampuan merencanakan pembelajaran sehingga kemampuan tersebut harus terus ditingkatkan. Melalui penelitian ini diharapkan dapat memberikan sumbangsih pemikiran tentang dampak model pembelajaran inovatif dalam hal ini model pembelajaran RADEC terhadap kemampuan guru dalam merencanakan

pembelajaran

di sekolah dasar.

\section{B. Metode Penelitian}

Pada bagian ini menjelaskan metodologi yang digunakan dalam penelitian. Metode penelitian ini menggunakan metode kuasi eksperimen, penelitian kuasi eksperimen berfungsi untuk mengetahui pengaruh percobaan/perlakuan terhadap sejumlah subjek yang telah di tentukan oleh peneliti (Faelasofi, Arnidha, \& Istiani, 2015). Penelitian dengan metode kuasi eksperimen ini ditentukan apabila peneliti hendak menerapkan suatu perlakukan atau tindakan kepada subjek penelitian. Adapun penelitian kuasi eksperimen pada penelitian ini menggunakan desain one shot case study. Instrumen yang digunakan dalam penelitian ini menggunakan lembar observasi, studi dokumentasi, dan penilaian kemampuan merencanakan pembelajaran. Studi dokumentasi dilakukan untuk melihat rencana pembelajaran yang dibuat oleh calon guru yang menjadi sampel dalam penelitian ini.

Indikator penilaian kemampuan merencanakan proses pelaksanaan pembelajaran dalam penelitian ini 
adalah (1) Penetapan KI, KD dan indikator; (2) Perumusan Tujuan; (3) Cakupan Materi; (4) Metode Kegiatan Pembelajaran; (5) Media/Alat, Bahan, dan Sumber Belajar; (6) Skenario Pembelajaran; (7) Penilaian Pembelajaran. Instrumen penelitian ini telah melalui proses validasi oleh beberapa ahli sehingga layak untuk digunakan dalam penelitian ini.

Prosedur dalam penelitian ini pertama-tama dilakukan treatment dengan menerapkan model pembelajaran RADEC selama satu kali pertemuan. Implementasi model pembelajaran RADEC dimulai dari calon guru membaca materi-materi esensial melalui tugas prapembelajaran yang diberikan dosen. Tugas prapembelajaran ini dikerjakan calon guru di rumah sebelum siswa belajar di sekolah. Tugas prapembelajaran berisi materimateri esensial yang perlu dikuasai. Tahap kedua adalah calon guru menjawab pertanyaan-pertanyaan prapembelajaran. Pertanyaan tersebut merupakan pertanyaan yang menuntut siswa untuk berpikir tingkat tinggi. Selanjutnya tahap ketiga adalah diskusi. Pada tahap ini, calon guru berdiskusi secara aktif terkait materi yang telah dipelajari dan membahas jawaban dari pertanyaan prapembelajaran yang sudah dikerjakan. Kemudian tahap keempat adalah tahap menjelaskan. Pada tahap ini calon guru menjelaskan materi yang dipelajari dan didiskusikan secara klasikal. Pada tahap ini juga, dosen dapat menjelaskan materi esensial yang dirasa belum dikuasai oleh calon guru. Tahap terakhir dari model pembelajaran RADEC adalah tahap membuat karya. Karya yang dibuat calon guru dalam penelitian ini adalah rancangan proses pembelajaran di sekolah dasar. Setelah dilakukan treatment, selanjutnya dilakukan observasi. Observasi yang dilakukan dalam penelitian ini adalah observasi hasil rencana pelaksanaan pembelajaran yang dibuat oleh calon guru.

\section{C.Hasil Penelitian dan Pembahasan}

Berdasarkan hasil penelitian, kemampuan calon guru dalam membuat rencana pelaksanaan pembelajaran dapat dilihat pada gambar berikut. 


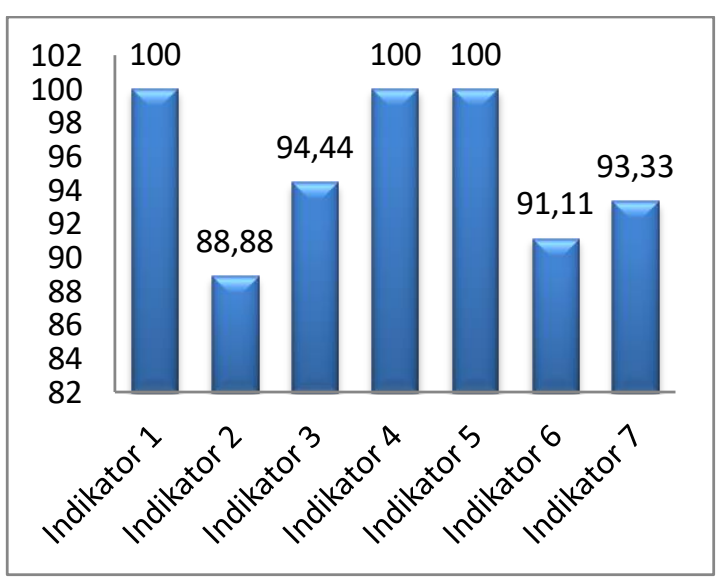

Gambar 1.1

Gambar 1.1 menunjukkan bahwa indikator kemampuan calon guru membuat rencana pelaksanaan pembelajaran yang paling tinggi diantara indikator lainnya adalah indikator 1 (Penetapan KI, KD dan indikator), indikator 4 (Metode Kegiatan Pembelajaran), dan indikator 5 (Media/Alat, Bahan). Ketiga indikator tersebut memperoleh skor 100. Hal ini menunjukkan bahwa kemampuan calon guru dalam menetapkan Kompetensi Inti, Kompetensi Dasar, Indikator dan, penggunaan metode pembelajaran, serta penggunaan media, alat, dan bahan pembelajaran menunjukkan kemampuan yang sangat baik setelah diberikan pembelajaran menggunakan model pembelajaran
RADEC. Indikator yang paling rendah diantara indikator lainnya adalah indikator 2 (perumusan tujuan) yakni memperoleh skor 88,88 . Hal ini berarti kemampuan calon guru dalam merumuskan tujuan masih belum maksimal dan perlu terus dikembangkan.

Secara keseluruhan, kemampuan calon guru membuat rencana pelaksanaan pembelajaran setelah diberikan pembelajaran menggunakan model RADEC termasuk dalam kategori sangat baik. Hal ini terlihat dari skor rata-rata yang diperoleh yaitu sebesar 95,39. Model pembelajaran RADEC mendorong calon guru untuk mengembangkan kemampuan kognitif melalui tugas prapembelajaran yang diberikan dosen. Hal ini menunjukkan bahwa kemampuan calon guru dalam menetapkan KI, KD, Indikator, Pemilihan metode yang sesuai dengan materi ajar dan pemilihan media, bahan, dan alat. Langkahlangkah model pembelajaran RADEC 
Pendas : Jurnal IImiah Pendidikan Dasar, ISSN Cetak : 2477-2143 ISSN Online : 2548-6950 Volume IV Nomor 01, Juni 2019

mendorong calon guru untuk mengembangkan keterampilan calon guru dalam merencanakan pembelajaran.

Tugas prapembelajaran yang terdapat dalam langkah-langkah model RADEC dapat mendorong calon guru untuk belajar secara mandiri memahami materi esensial yang diperlukan calon guru yang kemudian calon guru diminta untuk mendiskusikan pemahamannya bersama yang lainnya. Kegiatan tersebut penting bagi perkembangan kognitif calon guru karena kemampuan kognitif calon guru dapat berkembang apabila diberikan kesempatan untuk belajar secara mandiri dan memberikan kesempatan kepada calon guru untuk berinteraksi sosial melalui kegiatan diskusi (Vygotsky, 1962).

Model pembelajaran RADEC memberikan dampak positif kepada calon guru melalui langkah-langkah pembelajaran yang mendorong calon guru untuk beroleh pemahaman yang tinggi terkait rencana pelaksaan pembelajaran. Pengetahuan dan pemahaman calon guru yang baik dapat memudahkan calon guru dalam membuat rencana pelaksanaan pembelajaran (Alexander, DePalma, \& Ringer, 2016).

Langkah-langkah

model pembelajaran RADEC mendorong calon guru untuk mengembangkan kemampuan kognitif melalui tugas prapembelajaran yang diberikan dosen. Tugas prapembelajaran yang diberikan mendorong calon guru untuk belajar secara mandiri memahami materi esensial yang diperlukan terkait penyusunan rencana pelaksanaan pembelajaran. yang kemudian siswa diminta untuk Dalam tugas prapembelajaran tersebut, calon guru juga didorong untuk menjawab pertanyaan-pertanyaan

prapembelajaran. Pertanyaanpertanyaan yang diberikan kepada calon guru merupakan pertanyaan yang bersifat low order thinking sampai high order thinking dengan 
harapan calon guru dapat menguasai bagaimana membuat perencanaan pelaksanaan pembelajaran yang baik.

Dalam kegiatan menulis atau membuat rencana pelaksanaan pembelajaran, komponen kognitif berpengaruh secara signifikan dalam meningkatkan kemampuan menulis dan meningkatkan kemampuan calon guru dalam merencanakan pembelajaran (Decker, Roberts, Roberts, \& Stafford, 2016). Hal ini dikarenakan membuat perencanaan pembelajaran merupakan kegiatan yang menuntut calon guru untuk berpikir tingkat tinggi karena melibatkan sistem yang kompleks, sehingga untuk bisa membuat perencanaan pelaksanaan pembelajaran yang baik, calon guru harus berupaya dengan keras diiringi dengan intensitas membaca yang tinggi (Akkaya \& Kirmizi, 2010; Soltani, \& Kheirzadeh, 2017).

Kegiatan diskusi yang terdapat dalam model pembelajaran RADEC membantu calon guru untuk bisa menggali lebih dalam bagaimana membuat perencanaan pembelajaran di sekolah dasar yang baik sehingga calon guru memiliki pemahaman yang lebih terkait komponen-komponen apa saja yang harus dikembangkan dalam membuat perencanaan pembelajaran. Lebih lanjut, kegiatan menjelaskan yang terdapat dalam sintaks model RADEC dapat menambah wawasan dan memperdalam pemahaman calon guru terkait metode atau media pembelajaran yang relevan dan dapat mengembangkan keterampilan berpikir dan memudahkan siswa dalam menguasai pembelajaran. Lebih lanjut, tahap terakhir yang terdapat dalam model pembelajaran RADEC adalah tahap mencipta. Pada tahap ini calon guru membuat rencana pelaksanaan pembelajaran berdasarkan hasil pemikirannya sendiri. Kegiatan tersebut dapat memberikan dampak yang baik bagi calon guru yaitu dapat mengembangkan keterampilan berpikir kritis dan kreatif. Kegiatan 
Pendas : Jurnal IImiah Pendidikan Dasar, ISSN Cetak : 2477-2143 ISSN Online : 2548-6950

Volume IV Nomor 01, Juni 2019

yang melibatkan calon guru dalam pengambilan keputusan dalam menentukan apa yang ingin dibuat dapat membuat calon guru menjadi lebih bertanggung jawab atas pekerjaannya (Bonyadi \& Zeinalpur, 2014).

Secara
kemampuan calon guru dalam
merencanakan pembelajaran di
sekolah dasar termasuk dalam
kategori sangat baik setelah diberikan
perlakuan menggunakan model
pembelajaran RADEC. Hal ini sejalan
dengan penelitian-penelitian
sebelumnya bahwa melalui
implementasi model pembelajaran

RADEC dapat membantu para peserta didik menguasai materi pelajaran dan dapat mengembangkan keterampilan abad ke-21. (Handayani \& Sopandi, 2019; Pratiwi, Sopandi, \& Rosdiono, 2018). Selain itu, terdapat penelitian lain yang menunjukkan bahwa model pembelajaran RADEC dapat mendorong siswa untuk beroleh pemahaman konseptual yang baik dan mampu mengembangkan kemampuan menjelaskan siswa (Lukmanudin, 2018).

Berkaitan dengan uraian di atas, selain memiliki keunggulan, model pembelajaran RADEC memiliki hambatan dalam pelaksanaanya. Hambatan yang terjadi di lapangan selama menggunakan model pembelajaran RADEC diantaranya adalah kebiasaan calon guru dalam belajar yang hanya menerima penjelasan dari dosen ketika ditugaskan untuk membaca dan menjawab pertanyaan prapembelajaran banyak yang kurang antusias dalam menjalaninya. Hambatan kedua dalam implementasi model RADEC adalah kebiasaan calon guru yang belum terbiasa membuat pertanyaan penyelidikan, ketika ditugaskan untuk membuat pertanyaan penyelidikan masih terlihat kesulitan sehingga membutuhkan waktu yang cukup lama.

Dari uraian di atas, secara 
Pendas : Jurnal IImiah Pendidikan Dasar, ISSN Cetak : 2477-2143 ISSN Online : 2548-6950

Volume IV Nomor 01, Juni 2019

keseluruhan meskipun dalam implementasinya model pembelajaran RADEC masih memiliki hambatanhambatan yang masih perlu terus diantisipasi akan tetapi terbukti mampu meningkatkan kemampuan calon guru dalam merencanakan pembelajaran di sekolah dasar. Implementasi model pembelajaran RADEC ini memiliki implikasi dalam pembelajaran yaitu dapat membuat pembelajaran menjadi lebih aktif, mendorong calon guru untuk mengembangkan keterampilan abad ke-21 salah satunya adalah keterampilan menjelaskan. Selain itu, melalui penerapan model RADEC dapat meningkatkan kebiasaan membaca calon guru karena dalam model pembelajaran RADEC, sebelum memulai pembelajaran di kelas, calon guru terlebih dahulu ditugaskan untuk membaca bahan ajar yang diberikan dosen dan disarankan untuk membaca dari referensi lainnya.

Selain implikasi di atas, penerapan model pembelajaran RADEC juga memiliki dampak pengiring diantaranya adalah dapat meningkatkan literasi siswa tentang keragaman sosial dan budaya, terbentuknya kemandirian siswa dalam belajar dan memproduksi karya, meningkatnya kebiasaan membaca siswa, terbinanya kemampuan siswa dalam berkolaborasi, berpikir terbuka, dan berpikir visioner, serta berpikir kreatif.

\section{E. Kesimpulan}

Berdasarkan hasil penelitian, kemampuan calon guru dalam merencanakan pembelajaran di sekolah dasar mendapatkan skor ratarata sebesar 95,39. Hal ini menunjukkan bahwa model pembelajaran RADEC memiliki dampak yang signifikan terhadap kemampuan calon guru dalam membuat perencanaan pembelajaran. Indikator yang memperoleh skor paling tinggi diantara indikator lainnya adalah indikator kemampuan 
menetapkan kompetensi inti, kompetensi dasar, indikator dan kemampuan memilih metode serta kemampuan memilih media, alat dan bahan ajar. Sementara indikator kemampuan calon guru dalam merencanakan pembelajaran yang belum mendapatkan nilai maksimal adalah indikator kemampuan guru dalam merumuskan tujuan, cakupan materi, menyusun skenario pembelajaran dan membuat penilaian pembelajaran. Model pembelajaran RADEC memiliki implikasi dalam pembelajaran yaitu dapat mendorong calon guru untuk lebih gemar membaca, aktif dalam belajar, berdiskusi, mengemukakan pendapat, dan mendorong calon guru untuk lebih kreatif dan produktif.

\section{DAFTAR PUSTAKA}

Akkaya, N., \& Kirmizi, F. S. (2010). Relationship between attitudes to reading and time allotted to writing in primary education. Procedia - Social and Behavioral Sciences, 2(2), 4742-4746. https://doi.org/10.1016/j.sbspro. 2010.03.761.

Alexander, K. P., DePalma, M. J., \& Ringer, J. M. (2016). Adaptive Remediation and the Facilitation of Transfer in Multiliteracy Center Contexts. Computers and Composition, 41, 32-45. https://doi.org/10.1016/j.compco m.2016.04.005

Allison, E., \& Allison, E. (2018). Modern Scientific Literacy: A Case Study of Multiliteracies and Scientific Practices in a Fifth Grade Classroom. 270-283.

Binkley, M., et. al. (2012). Defining Twenty-First Century Skills. dalam Griffin, P. Assesment and Teaching of $21^{\text {st }}$ Century Skills. New York: Springer.

Bonyadi, A., \& Zeinalpur, S. (2014). Perceptions of Students Towards Self-selected and Teacher-assigned Topics in EFL Writing. Procedia - Social and Behavioral Sciences, 98, 385- 
391.

https://doi.org/10.1016/j.sbspro. 2014.03.430.

Decker, S. L., Roberts, A. M., Roberts, K. L., \& Stafford, A. L. (2016). Cognitive components of developmental writing skill. 53(6).https://doi.org/10.1002/pits

Faelasofi, R., Arnidha, Y., \& Istiani, A. (2015). Metode Pembelajaran Mind Mapping untuk Meningkatkan Kemampuan Komunikasi Matematik Siswa Dalam Pemecahan Masalah Matematika. JURNAL E-Du Math, 1(2). https://doi.org/10.26638/je.116.2 064.

Hamdu, G., \& Agustina, L. (2011). Pengaruh motivasi belajar siswa terhadap prestasi belajar IPA di sekolah dasar. Jurnal Penelitian Pendidikan, 12(1), 90-96.

Herman, T. (2007). Pembelajaran berbasis masalah untuk meningkatkan kemampuan berpikir matematis tingkat tinggi siswa sekolah menengah pertama. Educationist, 1(1), 4756.

Kependidikan, D. T., JENDERAL, D., Kependidikan, P., \& NASIONAL, D. P. (2008). Penilaian kinerja guru. Jakarta: Departemen Pendidikan Nasional.

Lukmanudin. (2018). Penguasaan Konsep IPA dan Kemampuan Menjelaskan Fenomena Perpindahan Zat Pencemar Melalui Pembelajaran RADEC (Tesis, Universitas Pendidikan Indonesia, 2018).

Morocco, C. C., Aguilar, C. M., \& Bershad, C. J. (2010). Supported Literacy for Adolescents.: Transforming Teaching and Content Learning for the 21st Century. John Wiley \& Sons.

Nurgiyantoro, B. (2010). Penilaian Pembelajaran Sastra Berbasis Kompetensi. Yogyakarta: BPFE. Pemerintah Republik Indonesia. (2003). Undang-Undang Republik Indonesia Nomor 20 
Tahun 2003 tentang Sistem Pendidikan Nasional. Sekretariat Negara Republik Indonesia. Jakarta.

Saragih, A. H. (2008). KOMPETENSI MINIMAL SEORANG GURU DALAM MENGAJAR. Jurnal Tabularasa, 5, 23-34.

Sardiman, A. M. (2004). Interaksi \& motivasi belajar mengajar. Rajagrafindo persada (rajawali pers).

Soltani, A., \& Kheirzadeh, S. (2017). JOURNAL OF LANGUAGE AND LINGUISTIC STUDIES

Exploring EFL students ' use of writing strategies and their attitudes towards reading-towrite and writing-only tasks, 13(2), 535-560.

Pratiwi, N., Sopandi, W., \& Rosdiono, M. (2018). The Students' Conceptual Understandings on Global Warming through ReadAnswer- Disscuss-Explain-and Create (RADEC) Learning. Proceedings of International
Conference on Elementary Education, 635-639.

Sopandi, W., \& Handayani, H. (2019). The Impact of Workshop on Implementation of (RADEC) Learning Model on Pedagogic Competency of Elementary School Teachers. International Conference of Innovation in Education (ICoIE) 178, pp. 7-11.

Sopandi, W., Pratama, Y., \& Handayani, H. (2019). Sosialisasi dan Workshop Implementasi Model

Pembelajaran RADEC Bagi Guru-Guru Pendidikan Dasar dan Menengah. Jurnal Pedagogia, Vol. 8 (1), 19-34.

Sopandi, W. (2017). The quality improvement of learning processes and achievements through the read-answer-discussexplain-and create learning model implementation. Proceeding 8th Pedagogy International Seminar 2017: Enhancement of Pedagogy 
in Cultural Diversity Toward

Excellence in Education, 8(229), 132-139.

Sudjana. (1983). Teknik analisis regresi dan korelasi bagi para peneliti. Tarsito, Bandung.

Vygotsky, L.S. (1962). Thought and Language: Kap. 6 The Development of Scientific Concepts in Childhood, Übersetzt von Eugenia Hanfmann und Gertrude Vakar, New York and London: MIT Press - John Wiley \& Sons, Inc, S.

Zandvakili, E., Washington, E., Gordon, E., \& Wells, C. (2018). Mastery Learning in the Classroom: Concept Maps, Critical Thinking, Collaborative Assessment (M3CA) Using Multiple Choice Items (MCls), 7(6), $45-56$.

https://doi.org/10.5539/jel.v7n6p $\underline{45}$. 